\section{Protection of the Galapagos Fauna}

THE giant tortoises and large iguanid lizards, which are a noteworthy feature of the fauna of the Galapagos Islands, have been greatly reduced in numbers during the last hundred and fifty years on account of their value as a source of oil, meat and leather. Many species are already extinct, and the numbers of others have passed below that minimum limit beyond which a species is unlikely to recover. Their commercial importance has now largely disappeared, but a new factor has arisen which menaces not only the larger reptiles but also the whole fauna. Pigs, dogs, cats and rats, introduced by settlers and visiting ships, are rapidly multiplying and preying heavily on the indigenous population. The danger has been apparent for many years, but it is only recently that a group of American zoologists, associated with the American Committee for International Wild Life Protection, has prevailed upon the Government of Ecuador to enact legislation to protect the fauna. The British Association has expressed to the Government of Ecuador its deep appreciation of the action taken, and has instructed its representative at the forthcoming International Zoological Congress (Dr. W. T. Calman) to direct attention to the matter. Unfortunately, the full scope of the Ecuadorian decree is not at present known in England, but it seems that permission has been given for many of the islands to be set aside as Nature reserves, and for the protection of the native reptiles, birds and aquatic mammals throughout the entire archipelago. No provision appears to have been made for the enforcement of the decree, but it is hoped that an international committee may be formed to co-operate with the Government of Ecuador to achieve this end; Sir Edward Poulton and Mr. H. W. Parker having been nominated by the British Association as its representatives.

\section{Science and Population Problems}

SIR ARnold WILson's public lecture to members of the British Association and others delivered at Norwich on September 9, which dealt with "Science and Population Problems", was a striking illustration of the manner in which the Association may contribute to the discussion of current problems of public policy and government. On these occasions of general assembly of the members, a considered statement on broad lines reaches a wider audience than that to which it is immediately addressed, and in pointing out the bearing of the results of scientific research on the method of approach to a solution of difficulties of the day, it can help to mould public opinion on sane and enlightened lines. Thus, for example, Sir Arnold Wilson, although showing in the latter part of his address that he had in mind more particularly the practical measures dictated by scientific study for dealing with a stationary or falling population in Great Britain, indicated by his wide survey of the facts, so far as known, throughout the world, that population problems assume a different complexion when viewed as a whole. He restored the perspective, which has been lost in recent discussion owing to post-War developments, by reminding his hearers that if in certain countries a stationary or falling population is a menace, a vast proportion of the world population -in the East alone, at least one third-is in immediate or prospective danger of under-nourishment or even starvation through pressure of population and economic stress. This fact, which was patent before the War and was emphasised time and again by the late Prof. J. W. Gregory, has been allowed to fall into the background in the discussion of more insistent social and economic sectional problems. Its implica. tions are no less grave than they were, and call as urgently as ever for consideration-possibly along the line of the scientific study of the distribution of commodities.

\section{Further Exploration of Zimbabwe}

Notwithstandinc the general acceptance of the results of Miss Caton-Thompson's excavations in Rhodesia in 1929, a section of archæological opinion in South Africa still adheres to the view that the Zimbabwe are more ancient than was then shown, and the work of a people other than of Bantu stock. It will be remembered that when. Miss CatonThompson submitted her results to the British Association, on behalf of which her excavations had been carried out, at the South African meeting in that year, Prof. Raymond Dart contested her conclusions, arguing for both the greater antiquity of the ruins and their lack of similarity to anything known in indigenous Bantu culture. An alternative suggestion is that they are of pre-Bantu origin, possibly the work of an Hamitic people under Arabian direction. Further research by South African archæologists, carried out after 1929, tends to confirm, rather than weaken, the view that structures of stone were not alien to early Bantu culture. Such, at least, is the origin attributed to ancient structures, which might, it is thought, have developed into the Zimbabwe, culminating in the unmortared granite towers and walls, thirty feet high and fifteen feet thick, of Great Zimbabwe. It is now reported from South Africa (Observer, September 6) that Prof. Dart, who has just returned to Johannesburg from Southern Rhodesia, proposes a further and more intensive exploration of Great Zimbabwe on a scale which will take five years for completion.

\section{Romano-Celtic Temple at Colchester}

Further excavation on the Romano-British site at Colchester has revealed more fully the character and purpose of the remarkable enclosure and contained building discovered at Sheepen Farm on the banks of the Colne. The course of the northern wall has now been followed up, and the entire enclosure traced. It is found to be approximately rectangular in plan, except that the north-east corner has been deflected a distance of $155 \mathrm{ft}$., thus reducing the eastern face of the enclosure to a length of $180 \mathrm{ft}$. The total perimeter of the enelosing wall is roughly 511 yards. Further details of the enclosed building, of which the purpose is now evident, are given in a 